\title{
Color evaluation of a resin cement light polymerized by different light sources and submitted to potentially staining beverages
}

\author{
Avaliação da cor de um cimento resinoso fotopolimerizado por diferentes fontes de luz e submetidos a \\ bebidas potencialmente corantes
}

\begin{abstract}
Tatiane Cristina DOTTA ${ }^{\text {a* }}$, Vinicius Cappo BIANCO ${ }^{\mathrm{b}}$, Alma Blásida Concepción Elizaur Benitez CATIRSE, Mayara Manfrin ARNEZ ${ }^{\mathrm{a}}$, Raisa CASTELO ${ }^{\mathrm{a}}$, Ana Paula Terossi de GODOI
\end{abstract}

\author{
${ }^{a}$ USP - Universidade de São Paulo, Faculdade de Odontologia, Ribeirão Preto, SP, Brasil \\ bUNIARARAS - Fundação Hermínio Ometto, Araras, SP, Brasil
}

\begin{abstract}
Resumo
Introdução: A estabilidade de cor dos cimentos resinosos, sejam eles de presa dual ou fotopolimerizáveis, assim como a cor do substrato dental, são fundamentais para o sucesso estético das restaurações cerâmicas uma vez que a cerâmica apresenta alto nível de translucidez devido a sua pequena espessura. Objetivo: $\mathrm{O}$ objetivo deste estudo in vitro foi avaliar a cor de um cimento resinoso fotopolimerizado por diferentes fontes de luz e imersos em bebidas potencialmente corantes. Material e método: Foram confeccionados 42 espécimes do cimento resinoso Variolink-Esthetic $(2 \times 6 \mathrm{~mm})(\mathrm{n}=7)$, sendo metade fotopolimerizado com luz LED (F1) e metade com luz Halógena (F2). Os espécimes foram mantidos em saliva artificial à $37^{\circ} \mathrm{C} \pm 1{ }^{\circ} \mathrm{C}$. Após 24 horas, foram polidos com discos abrasivos e subdivididos para serem imersos 2 minutos por dia, durante 28 dias, nas diferentes soluções: S1 - Coca-Cola; S2 - Vinho Tinto; e S3 - Água destilada (controle). Foram realizadas 5 leituras de cor: T0 - inicial; T1 - 7 dias; T2 - 14 dias; T3 - 21 dias; e T4 - 28 dias; com auxílio de um espectrofotômetro (modelo SP62S). Os dados de alteração de cor $\left(\Delta \mathrm{E}^{*}\right)$ foram submetidos a análise estatística, ANOVA e Tukey ( $\mathrm{p} \leq 0,05)$. Resultado: Analisando o fator solução, $\mathrm{S} 2(5,89( \pm 0,02))$, proporcionou maior $\Delta \mathrm{E}^{\star}$ que $\mathrm{S} 1(3,79( \pm 0,02))$ e este (S1), maior que S3 $(1,41( \pm 0,02))$. Analisando o fator fonte de luz, F2 $(4,05( \pm 0,12))$, proporcionou maior $\Delta \mathrm{E}^{\star}$ que F1 $(3,33( \pm 0,12))$. $\mathrm{E}$ analisando o fator tempo, obteve-se que $\Delta \mathrm{E}^{*}$ foi gradativamente aumentando no decorrer do tempo: T1 $(2,36( \pm 0,08))$; T2 $(3,27( \pm 0,08)) ; \mathrm{T} 3(4,06( \pm 0,08)) ;$ e T4 $(5,09( \pm 0,08))$. Conclusão: Conclui-se que o vinho tinto promoveu maior alteração de cor; a luz Halógena promoveu maior pigmentação e; quanto maior o tempo de imersão, maior alteração de cor do material.
\end{abstract}

Descritores: Cor; cimentos dentários; bebidas.

\begin{abstract}
Introduction: The color stability of resin cements, whether dual-pre-cured or photopolymerizable, as well as the color of the dental substrate, are fundamental for the aesthetic success of ceramic restorations, since the ceramic presents a high level of translucency due to its small thickness. Objective: The aim of this in vitro study was to evaluate the color of a resin cement light polymerized by different light sources and immersed in potentially staining beverages. Material and method: Were made 42 specimens of resin cement Variolink-Esthetic $(2 \times 6 \mathrm{~mm})(\mathrm{n}=7)$, being half polymerized with LED light (F1) and half with Halogen light (F2). The specimens were stored in artificial saliva at $37^{\circ} \mathrm{C} \pm 1^{\circ} \mathrm{C}$. After 24 hours, they were polished with abrasive discs, and divided for the purpose of being submitted to the different solutions for 2 minutes per day, for 28 days, as follows: S1 - Coca-Cola; S2 - Red Wine; and S3 - Distilled Water (Control). Five color readouts were taken: T0 - initial; T1 - 7 days; T2 - 14 days; T3 - 21 days; and T4 - 28 days; with a spectrophotometer (Model SP62S). The color change data $\left(\Delta \mathrm{E}^{\star}\right)$ were submitted to statistical analysis, ANOVA and Tukey ( $\left.\mathrm{p} \leq 0.05\right)$. Result: Analyzing the factor solution, $\mathrm{S} 2(5.89( \pm 0.02))$, produced a higher $\Delta \mathrm{E}^{\star}$ value than $\mathrm{S} 1(3.79( \pm 0.02))$ and $(\mathrm{S} 1)$, a higher value than $\mathrm{S} 3$ $(1.41( \pm 0.02))$. Analyzing the factor light source, F2 $(4.05( \pm 0.12))$, produced a higher $\Delta \mathrm{E}^{\star}$ value than F1 $(3.33( \pm 0.12))$. When analyzing the factor time, $\Delta \mathrm{E}^{*}$ values were found to increase gradually over the course of time: $\operatorname{Tl}(2.36( \pm 0.08))$; $\mathrm{T} 2(3.27( \pm 0.08))$; T3(4.06 $( \pm 0.08))$; and T4(5.09 $( \pm 0.08))$. Conclusion: It was concluded that red wine produced a greater color change; Halogen light promoted highest degree of pigmentation; and the longer the time of immersion, the greater the color change of the material.
\end{abstract}

Descriptors: Color; dental cements; beverages. 


\section{INTRODUCTION}

At present, there is great demand for esthetic restorations and materials with adequate mechanical and physical properties in Dentistry. With the increasing number of esthetic procedures, resin cements are those most indicated for cementing ceramic restorations, due to their excellent esthetic appearance and good mechanical properties, such a flexural and compressive strength ${ }^{1}$.

Resin cements are composite resins, however, with a smaller quantity of filler, so that they have the fluidity required for cementation. That is to say, they are based on the BIS-GAMA (Bisphenol-A glycidyl methacrylate) monomer system, in combination of low viscosity monomers, and inorganic fillers (glasses with metal fillers, $\mathrm{Si}_{2}$ ) treated with silane ${ }^{2}$.

They are available in different formulations, according to their mechanism of polymerization, namely self polymerizing resin cements, light activated cements, and dual activation cements (chemical and light activated). The cements exclusively activated by light offer clinical advantages in comparison with other cements, because they require a longer working time, their polymerization is controlled by the operator and the material has greater color stability. However, their use is limited to situations in which the thickness and color of the restoration do not affect the polymerization capacity of the activating light, as in cases of cementation of esthetic veneers and inlays with shallow preparation boxes ${ }^{3}$.

Although light polymerizing resins cements are more stable where color is concerned, a previous study has demonstrated that light polymerizing, self-polymerizing and dual polymerizing cements could undergo color change with the passage of time ${ }^{4}$. From this aspect, Akay, Taniş ${ }^{5}$ has pointed out that superficial staining at the interface of ceramic restorations due to the presence of cementing agents was related to the penetration of dyes contained in foods, and even due to aging to which restorations are susceptible in the oral cavity. Furthermore, Pereira et al. ${ }^{6}$ pointed out that oral hygiene is one of the important factors in color stability, since the presence of biofilm and its products causes degradation of the material and facilitates its pigmentation.

Added to this, the cause of resin material discoloration is known to be attributable to intrinsic and extrinsic factors. Intrinsic factors are represented by discoloration of the material itself, and the change in resin matrix, matrix interface and filler. Moreover, color changes of cements may be aggravated by roughness, surface microhardness and extrinsic factors. These in turn, are intensified by oral hygiene, diet, drinking and smoking habits, type of pigmenting solution, $\mathrm{pH}$, frequency of ingestion, and time in contact with the material ${ }^{7,8}$.

In addition, to obtain success with and longevity of resin cements, it is of fundamental importance for these materials used for the fixation of indirect restorations to reach the highest possible degree of polymerization. Inadequate polymerization may lead to marginal microleakage due to adhesive failures and reduction in the physical and mechanical properties of the material'.
There are various types of appliances for light polymerization of resin cements, among them, those based on halogen light, and light emitting diodes (LED) ${ }^{9}$.

Halogen light is the source most used to induce polymerization in resin-based dental materials. These appliances emit a continuous spectrum of light, although only a small part of the spectrum is useful for polymerization. The light emitting diode (LED) lights recently developed offer a much narrower emission spectrum. In general, Led lights have the following advantages when compared with halogen light: long life of over 10,000 hours, little degradation at the output of light over the course of time and resistance to shocks and vibrations ${ }^{10}$

Bearing in mind all the factors that could influence the color or resin cements, and consequently, the clinical success of ceramic restorations whose margins are exposed to the oral cavity, was the purpose of the authors in conducting this study. Since pure, ultrafine ceramic restorations are considerably expensive, and have been fabricated frequently in dental offices; and since little is known about their behavior, in view of the different clinical situations faced, such as the daily use of wines, coca cola, and the best manner to perform light polymerization of these materials. Thus, the aim of this in vitro study was to evaluate the color of a resin cement light polymerized by different light sources and immersed in potentially staining beverages.

\section{MATERIAL AND METHOD}

\section{Experimental Design and Materials}

The experiment sample consisted of 42 test specimens $(n=7)$, fabricated from light polymerizing resin cement, Variolink-Esthetic (Ivoclar Vivadent AG, Schaan/Liechtenstein, Europe), shade Warm+. The specimens were divided into two groups, and each group was light polymerized by a light source: LED or Halogen light. After fabrication, the test specimens were submitted to pigmenting challenges with three different solutions: Distilled water (control); Coca-Cola and Red Wine.

The color readouts $\left(\Delta \mathrm{E}^{*}\right)$ were taken in 5 time intervals: initial (24 hours after fabrication), 7, 14, 21 and 28 days.

Chart 1 follows below, with the description of the materials used for the research.

\section{Obtainment of Test Specimens}

The $2 \mathrm{~mm}$ thick test specimens were obtained with the aid of a Teflon matrix, $6 \mathrm{~mm}$ in diameter. The light polymerizing resin was inserted into the matrix in a single increment with the aid of a dual Titanium spatula (Millennium, Golgran, SP, Brazil). After inserting the material, a polyester matrix (K-Dent, Quimidrol, SC, Brazil) on a glass slide was placed on the specimen surface, and a load of $1 \mathrm{~kg}$ was placed on the glass slide (Golgran, SP, Brazil) for 30 s to guarantee that the entire matrix would be filled; the excess material would be extravasated, and that a smooth, standardized surface would be promoted for color readout. 
Chart 1. Description of materials that were used in the study

\begin{tabular}{|c|c|c|}
\hline Materials & Composition & Manufacturer \\
\hline $\begin{array}{l}\text { Resin cement } \\
\text { Variolink-Esthetic }\end{array}$ & $\begin{array}{c}\text { Urethane dimethacryate, methacrylate monomers } \\
\text { Inorganic fillers: ytterbium trifluoride, and spherical mixed oxides. } \\
\text { Initiators, stabilizers and pigments }\end{array}$ & $\begin{array}{l}\text { Ivoclar Vivadent AG } \\
\text { Schaan/Liechtenstein } \\
\text { Europe }\end{array}$ \\
\hline Cola Soft Drink & $\begin{array}{l}\text { Carbonated water, sugar, cola nut extract, caffeine, caramel IV coloring, acidulant } \\
\text { phosphoric acid and natural aroma. }\end{array}$ & $\begin{array}{l}\text { Coca Cola } \\
\text { Rio de Janeiro - RJ } \\
\text { Brazil }\end{array}$ \\
\hline Red Wine & Dry red table wine, sugar, stabilizer INS 353 and preservatives INS 202 and INS 224 & $\begin{array}{l}\text { Passarin Bebidas } \\
\text { Campinas/SP } \\
\text { Brazil }\end{array}$ \\
\hline Distilled Water & $\begin{array}{l}\text { Water obtained from the distillation apparatus, by means of ion exchange resin; ab- } \\
\text { sence of salts, minerals and chemical agents. }\end{array}$ & $\begin{array}{l}\text { FIT Destilacqua } \\
\text { Araraquara. } \\
\text { Brazil }\end{array}$ \\
\hline
\end{tabular}

After removal of the filler, the materials were light-polymerized; Thus, according to a series of groups, 21 specimens were polymerized by LED light (UltraLed - Dabi Atlante, Ribeirão Preto, Brazil), and the other 21 by halogen light (Optilight 600 - Gnatus, Ribeirão Preto, Brazil). The polymerization is performed at a distance of $2 \mathrm{~mm}$ from the surface of the floor ${ }^{11}$ according to the manufacturer's instructions and always using the orange eye protector of the photopolymerizer, being important to keep the light in the correct position and direction. During the polymerization process, the light intensity was verified by means of a radiometer (Radiometer; ECEL, São Paulo, SP, Brazil).

Subsequently, the specimens were removed from the matrix, and after 24 hours, they were polished with abrasive discs (Diamond Master, Joinville-SC, Brazil) in a descending sequence of granulation, at low speed, and periodically dampened, in accordance with the manufacturer's indications. The abrasive discs were changed after every 5 specimens, to prevent loss of abrasiveness from influencing the results found.

During the entire experiment, the specimens were kept in distilled water at a temperature of $37 \pm 1^{\circ} \mathrm{C}$.

\section{First Color Analysis}

The initial color readout was taken 24 hours after polishing the specimens.

For color evaluation, the spectrophotometer Model SP62S was used with Software Model QA Master I (X-Rite Incorporated - Neu-Isenburg, Germany). Each specimen was carefully manipulated with clinical forceps (Millennium, Golgran, SP, Brazil), dried with absorbent paper; and kept in a device duly prepared with niches for placement of the specimens and standardization of the readouts against an opaque white background.

The color measurements were obtained by means of the CIE $L^{\star} a^{*} b^{*}$ color system. The $\Delta E^{\star}$ value, that is, the total difference between two color stimuli was calculated by the following formula:

$$
\Delta \mathrm{E}^{\star}=\sqrt{\left(\Delta \mathrm{L}^{\star}\right)^{2}+\left(\Delta \mathrm{a}^{\star}\right)^{2}+\left(\Delta \mathrm{b}^{\star}\right)^{2}}
$$

The CIE $\mathrm{L}^{\star} \mathrm{a}^{\star} \mathrm{b}^{\star}$ system uses three parameters for defining color: luminosity (lightness), hue and saturation. Luminosity represent the degree of lightness and darkness of the object, represented by the value of $L^{*}$, with $L^{*}=100$ for white and $L^{*}=0$ for black. The parameters $\mathrm{a}^{*}$ and $\mathrm{b}^{*}$, called the chromatic scale (hue), represent red if $+\mathrm{a}^{*}$, and green if $-a^{*}$; yellow if $+b^{*}$, and blue if $-b^{*}$. The saturation and intensity of hue is given by the numerical value of $\mathrm{a}^{*}$ and $\mathrm{b}^{*}$. The values of $\Delta \mathrm{L}^{*}, \Delta \mathrm{a}^{*}, \Delta \mathrm{b}^{*}$, correspond to the difference in the values of $\mathrm{L}^{\star}, \mathrm{a}^{\star}, \mathrm{b}^{\star}$, respectively, in comparison with the first color readout (initial).

As previously mentioned, each specimen was carefully manipulated by using clinical forceps, avoiding manual contact with the evaluator, which could deposit residues and/or grease and influence the values that were found. The specimens were also carefully dried with absorbent paper to prevent interference of humidity in the color change values ${ }^{12}$.

\section{Immersion Procedures}

After initial color analysis, the test specimens were immersed for two minutes per day, for a period of 28 days; each group in its respective solution: Coca-Cola, red wine and distilled water.

\section{Subsequent Color Analyses (7, 14, 21 and 28 days)}

Every 7 days during the 28-day period of immersion in the respective solutions, new color readouts were taken, in the same manner as described for the initial color readout.

\section{Statistical Analysis}

The color change values $\left(\Delta \mathrm{E}^{*}\right)$ obtained were analyzed by means of the parametric three-way ANOVA test (Solution, Time and Type of Light), and the complementary Tukey test with a level of significance of 5\%. The statistical program GMC - version 2002 (Ribeirão Preto Dental School - SP, Brazil) was used. 


\section{RESULT}

The three-way analysis of variance demonstrated that there was statistical significance $(\mathrm{p} \leq 0.05)$ for the factors in isolation, and for all the interactions between the factors. For the factor Solution $(\mathrm{p}=0.0000)$ and Light Source $(\mathrm{p}=0.0023)$ statistically significant difference was verified between all the groups. Thus, the specimens submitted to red wine were observed to present a higher degree of color change $(5.89 \pm 0.02)$, followed by the Group immersed in cola soft drink $(3.79 \pm 0.02)$ and distilled water $(1.41 \pm 0.02)$. For the factor Light Source, the group light polymerized with halogen light was found to present a higher mean color change value $(4.05 \pm 0.12)$ than the group light polymerized with the LED light $(3.33 \pm 0.12)$. The mean values found and the statistically significant differences between the groups for the Factor Time in isolation ( $\mathrm{p}=0.0000)$, and for the interactions between the factors are shown in Tables 1, 2, 3 and 4 .

Table 1. Mean color change values $\left(\Delta \mathrm{E}^{\star}\right)$ for factor Time with their respective standard deviations

\begin{tabular}{cccc}
\hline $\mathbf{7}$ days & $\mathbf{1 4}$ days & $\mathbf{2 1}$ days & $\mathbf{2 8 ~ d a y s}$ \\
\hline $2.36( \pm 0.08)^{\mathrm{a}}$ & $3.27( \pm 0.08)^{\mathrm{b}}$ & $4.06( \pm 0.08)^{\mathrm{c}}$ & $5.09( \pm 0.08)^{\mathrm{d}}$ \\
\hline
\end{tabular}

Different letters indicate statistically significant difference among the groups $(\mathrm{p}<0.05)$; Critical Tukey value: 0.32 .

Table 2. Mean color change values $\left(\Delta \mathrm{E}^{\star}\right)$ for the interaction Light Source $\times$ Solution, with their respective standard deviations

\begin{tabular}{cccc}
\hline & $\begin{array}{c}\text { Cola Soft } \\
\text { Drink }\end{array}$ & Red Wine & $\begin{array}{c}\text { Distilled } \\
\text { Water }\end{array}$ \\
\hline $\begin{array}{c}\text { Halogen } \\
\text { Light }\end{array}$ & $4.31( \pm 0.19)^{\mathrm{B}, \mathrm{c}}$ & $6.47( \pm 0.19)^{\mathrm{C}, \mathrm{e}}$ & $1.38( \pm 0.19)^{\mathrm{A}, \mathrm{a}}$ \\
LED LIGHT & $3.27( \pm 0.19)^{\mathrm{E}, \mathrm{b}}$ & $5.30( \pm 0.19)^{\mathrm{E}, \mathrm{d}}$ & $1.44( \pm 0.19)^{\mathrm{D}, \mathrm{a}}$ \\
\hline
\end{tabular}

Different lower case letters represent statistically significant difference between the columns; Different capital letters represent statistically significant difference between the lines; $\mathrm{p}=0.00068$

\section{DISCUSSION}

Among the characteristics of resin cement, color stability is one of the most important parameters in the quest for esthetic success and longevity of indirect restorations ${ }^{8}$. Therefore, the authors decided to conduct this study, because esthetic restorations constantly present their supra gingival terminals, consequently exposing the resin cement to the oral cavity.

Nevertheless, the color change of these materials may be influenced by both intrinsic and extrinsic factors. As intrinsic factors related to color change, the degree of conversion of resin materials, composition of the resin matrix, size and distribution of filler particles, photo-initiator and the matrix and filler interface may be cited. Whereas, with reference to extrinsic factors, the type of pigmenting solution to which the cements are exposed must be considered, as well as the $\mathrm{pH}$, change in temperature, presence of water, frequency of ingesting foods and time in contact with the material ${ }^{7,8}$. Therefore, in the present study, a light polymerizing resin was evaluated after light polymerization by two light sources (related to possible changes of the intrinsic factor) and when exposed to different immersion media (extrinsic factors).

Taking into consideration that color determination is the result of a complex phenomenon, and to eliminate subjective errors in the evaluation of color change, in this study, a colorimeter was used which uses the CIE $\mathrm{L}^{*} \mathrm{a}^{\star} \mathrm{b}^{\star}$ system for defining color. The result given by this equipment is the variation in color $\left(\Delta \mathrm{E}^{\star}\right)$ between two different time intervals ${ }^{13}$. Thus, three different intervals are used to distinguish changes in the color values of esthetic restorations: $\Delta \mathrm{E}^{\star}<1$, imperceptible to the human eye; $1.0<\Delta \mathrm{E}^{*}<3.3$, seen only by persons with experience in the area, but is still considered clinically acceptable; and $\Delta \mathrm{E}>3.3$, easily observed; that is, clinically unacceptable $\mathrm{e}^{14-17}$.

Taking these parameters into consideration, with respect to the use of pigmenting solutions in the present study, color change perceptible by the human eye was verified when the test specimens were immersed in cola soft drink (3.79 \pm 0.02$)$ or red wine $(5.89 \pm 0.02)$.

Table 3. Mean color change values $\left(\Delta \mathrm{E}^{\star}\right)$ for the interaction Time $\times$ Solution, with their respective standard deviations

\begin{tabular}{ccccc} 
& $\mathbf{7}$ days & $\mathbf{1 4}$ days & 21 days & $\mathbf{2 8 ~ d a y s ~}$ \\
\hline Cola Soft Drink & $2.39( \pm 0.15)^{\mathrm{A}, \mathrm{b}}$ & $3.39( \pm 0.15)^{\mathrm{B}, \mathrm{b}}$ & $4.48( \pm 0.15)^{\mathrm{C}, \mathrm{b}}$ & $4.89( \pm 0.15)^{\mathrm{C}, \mathrm{b}}$ \\
Red Wine & $3.72( \pm 0.15)^{\mathrm{A}, \mathrm{c}}$ & $5.18( \pm 0.15)^{\mathrm{B}, \mathrm{c}}$ & $6.72( \pm 0.15)^{\mathrm{C}, \mathrm{c}}$ & $7.92( \pm 0.15)^{\mathrm{D}, \mathrm{c}}$ \\
Distilled Water & $0.95( \pm 0.15)^{\mathrm{A}, \mathrm{a}}$ & $1.23( \pm 0.15)^{\mathrm{A}, \mathrm{a}}$ & $1.00( \pm 0.15)^{\mathrm{A}, \mathrm{a}}$ & $2.45( \pm 0.15)^{\mathrm{B}, \mathrm{a}}$ \\
\hline
\end{tabular}

Different lower case letters represent statistically significant difference between the columns; Different capital letters represent statistically significant difference between the lines; $\mathrm{p}=0.0000$.

Table 4. Mean color change values $\left(\Delta \mathrm{E}^{*}\right)$ for the interaction Light Source $\mathrm{x}$ Time, with their respective standard deviations

\begin{tabular}{ccccc} 
& $\mathbf{7}$ days & $\mathbf{1 4}$ days & $\mathbf{2 1}$ days & $\mathbf{2 8 ~ d a y s}$ \\
\hline Halogen Light & $2.47( \pm 0.12)^{\mathrm{a}, \mathrm{A}}$ & $3.56( \pm 0.12)^{\mathrm{b}, \mathrm{B}}$ & $4.66( \pm 0.12)^{\mathrm{b}, \mathrm{C}}$ & $5.52( \pm 0.12)^{\mathrm{b}, \mathrm{D}}$ \\
LED LIGHT & $2.24( \pm 0.12)^{\mathrm{a}, \mathrm{A}}$ & $2.97( \pm 0.12)^{\mathrm{a}, \mathrm{B}}$ & $3.47( \pm 0.12)^{\mathrm{a}, \mathrm{B}}$ & $4.65( \pm 0.12)^{\mathrm{a}, \mathrm{C}}$ \\
\hline
\end{tabular}

Different lower case letters represent statistically significant difference between the columns; Different capital letters represent statistically significant difference between the lines; $\mathrm{p}=0.00027$. 
Statistically, specimens immersed in red wine presented a higher degree of color change, followed by the group immersed in cola soft drink, which was in agreement with the study of Ceci et al. ${ }^{17}$.

The fact that wine causes a higher level of pigmentation in resin materials in agreement with the studies of Freitas et al. ${ }^{16}$, and Ceci et al. ${ }^{17}$. The reason why wine stained with greater intensity may be due to the presence of tannin contained in red wine ${ }^{17}$, because grape pigments together with the presence of alcohol are known to lead to softening of the surface, thereby helping with the penetration of liquids ${ }^{18}$. Relative to the color change caused by cola soft drink, according to Ceci et al. ${ }^{17}$ this may be related to the presence of phosphoric acid in this product. Various authors ${ }^{19,20}$ have pointed out that the presence of alcohol and acid in beverages commonly used by the population may lead to the process of staining, due to softening of the surface of composites, and consequently, absorption of the coloring agents in these substance by the resin matrix ${ }^{21}$.

There was also color change in the specimens immersed in distilled water (1.41 \pm 0.02$)$, but this was imperceptible by the naked eye, or by persons with little experience in this area. According to Arregui et al. ${ }^{22}$, water sorption is one of the factors associated with discoloration of composites. Moreover, the structure of adhesive monomers influences the hydrophilicity of the resultant polymer. Other factors associated with water sorption are the type and quantity (\% vol.\% by weight) of filler particles used ${ }^{22}$.

Furthermore, according to Habib et al..$^{23}$ the color changes that occurred due to immersion in distilled water may be due to the penetration of water into the matrix or at the filler matrix interface. The presence of microfissures in the resin matrix as a result of the effects of swelling and plasticization, together with the interfacial gaps created between the filling material and the resin matrix may lead to color change.

According to Aguiar et al. ${ }^{24}$ one of the relevant factors in change in the color of resin cements is the degree of conversion, which is directly linked to the effectiveness of the curing process of cements. This is because failure in the degree of conversion of monomer into polymer may lead to oxidation of the non-reacted components, generating a higher level of water absorption and changing the original color. Thus, to guarantee better sealing capacity, less solubility, higher bond strength and better color stability, it is essential for the material to be capable of attaining a high degree of conversion ${ }^{8}$.

Available on the work market for polymerizing the materials, there is the conventional quartz-tungsten Halogen light (HL) and LED light (light-emitting-diode) ${ }^{25}$.

According to Bosquiroli et al. ${ }^{25}$, as a result of the high temperature at which the halogen lights operate, the bulb, reflector and filter are damaged; these have the important function of selecting the light energy at the wavelength necessary for sensitizing the photoinitiator. All of these factors interfere in the quality of the light emitted, affecting the degree of polymerization of the material.

There are few publications that have investigated the color stability of dental materials when polymerized with LED and Halogen light ${ }^{17}$. Knowing this, in the present study, the authors opted to compare the polymerization performed with LED and
Halogen light, and observed that the specimens polymerized by Halogen light presented a higher degree of color change than those light polymerized with LED light. This was in agreement with Rüttermann et al. ${ }^{15}$, who, in their study, evaluated the effect of polymerization by Quartz-Tungsten Halogen (QTH) and LED light on the color stability of resin-based restorative materials, considering the time of exposure. These authors concluded that when composite resin was polymerized with LED light, it presented color stability similar to that or even better, with an exposure time of only 10 s, than when it was performed with the quartz-tungsten halogen light with an exposure time of 20s. According to these authors, color stability depends on the quality of hardening, conversion of the photoinitiator system, and formulations of the materials. Moreover, during polymerization, initiators or synergists form by-products that discolor thermally, or under ultraviolet light, and displace the color or resin towards more red or yellow.

With respect to the factor time, in this study, the authors verified that the specimens presented higher mean color change values $\left(\Delta \mathrm{E}^{\star}\right)$ at 28 days (5.09 \pm 0.08$)$, and lower mean color change values $\left(\Delta \mathrm{E}^{*}\right)$ at 7 days $(2.36( \pm 0.08)$, which was in agreement with the studies of Shiozawa et al. ${ }^{1}$ and Abu-Bakr et al. ${ }^{7}$ in which they verified the change in color was greater in the first week of immersion of the specimens in the substances they tested, and that this change was increasing. This behavior was repeated for both light polymerization conditions; that it, for both Led and Halogen light, and also for the different solutions tested.

In spite of the limitations of in vitro studies in the evaluation of composite behavior, considering that the presence of saliva; the food bolus; temperature of liquids; quantity of ingestion and polishing action generated by daily tooth brushing had direct action on the physical-mechanical behavior of dental materials; these studies have allowed verification of the longevity of the materials and their clinical behavior, in addition to making it possible to provide patients with guidance about the best way to preserve their restorations.

Within the limitations of this in vitro study, the authors could conclude that red wine promoted a higher level of color change than the other solutions studied. The light source influenced the color of the cement studied; And the longer the immersion time, the higher was the degree of color change of the light polymerizing cement evaluated.

\section{CONCLUSION}

Within the limitations of this in vitro study, the authors could conclude that red wine promoted a higher level of color change than the other solutions studied. The light source influenced the color of the cement studied; and the longer the immersion time, the higher was the degree of color change of the light polymerizing cement evaluated.

\section{ACKNOWLEDGEMENTS}

To the Faculty of Dentistry of Ribeirão Preto - USP for authorizing the use of the laboratories for the execution of this research. 


\section{REFERENCES}

1. Shiozawa M, Takahashi H, Asakawa Y, Iwasaki N. Color stability of adhesive resin cements after immersion in coffee. Clin Oral Investig. 2015 Mar;19(2):309-17. http://dx.doi.org/10.1007/s00784-014-1272-8. PMid:24950608.

2. Prakki A, Carvalho RM. Cimentos resinosos dual: características e considerações clínicas. PGR: Pós-Grad. Rev. Fac. Odontol. São José dos Campos. 2001 Jan-Abr;4(1):21-6.

3. Pegoraro LF, Valle AL, Araujo CRP, Bonfante G, Conti PCR. Fixed prosthesis: bases for planning in oral rehabilitation. 2nd ed. São Paulo: Artes Médicas; 2013.

4. Nathanson D, Banasr F. Color stability of resin cements: an in vitro study. Pract Proced Aesthet Dent. 2002 Aug;14(6):449-55, quiz 456. PMid:12242855.

5. Akay C, Taniş MC. Evaluation of color changes of dental luting materials in food colorant solutions. Int J Artif Organs. 2017 Sep;40(9):503-9. http://dx.doi.org/10.5301/ijao.5000579. PMid:28574112.

6. Pereira SK, Muller AA, Boratto AC, Veiga PM. Avaliação da alteração de cor de resinas compostas em contato com soluções potencialmente corantes. UEPG Ci. Biol. Saúde. 2003;9:13-9.

7. Abu-Bakr N, Han L, Okamoto A, Iwaku M. Color stability of compomer after immersion in various media. J Esthet Dent. 2000;12(5):25863. http://dx.doi.org/10.1111/j.1708-8240.2000.tb00232.x. PMid:11338492.

8. Furuse AY, Santana LOC, Rizzante FAP, Ishikiriama SK, Bombonatti JF, Correr GM, et al. Delayed light activation improves color stability of dual-cured resin cements. J Prosthodont. 2018 Jun;27(5):449-55. http://dx.doi.org/10.1111/jopr.12509. PMid:27455118.

9. Accetta DF, Magalhães TR Fo, Weig KM, Fraga RC. Influência dos fotopolimerizadores (luz halógena x LED) na resistência à compressão de resinas compostas. Rev Fac Odontol Univ Nac. 2008 Set;49(3):17-9.

10. Watanabe H, Kazama R, Asai T, Kanaya F, Ishizaki H, Fukushima M, et al. Efficiency of the dual-cured resin cement polymerization induced by high-intensity LED curing units through ceramic material. Oper Dent. 2015 Mar-Apr;40(2):153-62. http://dx.doi.org/10.2341/13-357-L. PMid:25136906.

11. Pick B, Gonzaga CC, Steagall W Jr, Kawano Y, Braga RR, Cardoso PE. Influence of curing light attenuation caused by aesthetic indirect restorative materials on resin cement polymerization. Eur J Dent. 2010 Jul;4(3):314-23. PMid:20613921.

12. Brandão RB, Martin CCS, Catirse ABCEB, Castro e Silva M, Evison MP, Guimarães MA. Heat induced changes to dental resin composites: a reference in forensic investigations? J Forensic Sci. 2007 Jul;52(4):913-9. http://dx.doi.org/10.1111/j.1556-4029.2007.00474.x. PMid:17553091.

13. Fontes ST, Fernández MR, Moura CM, Meireles SS. Color stability of a nanofill composite: effect of different immersion media. J Appl Oral Sci. 2009 Sep-Oct;17(5):388-91. http://dx.doi.org/10.1590/S1678-77572009000500007. PMid:19936513.

14. Vichi A, Ferrari M, Davidson CL. Color and opacity variations in three different resin-based composite products after water aging. Dent Mater. 2004 Jul;20(6):530-4. http://dx.doi.org/10.1016/j.dental.2002.11.001. PMid:15134940.

15. Rüttermann S, Suyoun K, Raab WH, Janda R. Effect of exposure time on the color stability of resin-based restorative materials when polymerized with quartz-tungsten halogen and LED light. Clin Oral Investig. 2010 Oct;14(5):599-605. http://dx.doi.org/10.1007/s00784009-0316-y. PMid:19629544.

16. Freitas DB, Godoi APT, Trauth KGS, Colucci V, Catirse ABCEB. Study of the color alteration of esthetic restorative materials influenced by chlorhexidine associated with sweet red wine. Int J Clin Dent. 2012 Jan;5(2):113-20.

17. Ceci M, Viola M, Rattalino D, Beltrami R, Colombo M, Poggio C. Discoloration of different esthetic restorative materials: a spectrophotometric evaluation. Eur J Dent. 2017 Apr-Jun;11(2):149-56. http://dx.doi.org/10.4103/ejd.ejd_313_16. PMid:28729784.

18. Bagheri R, Burrow MF, Tyas M. Influence of food-simulating solutions and surface finish on susceptibility to staining of aesthetic restorative materials. J Dent. 2005 May;33(5):389-98. http://dx.doi.org/10.1016/j.jdent.2004.10.018. PMid:15833394.

19. Badra VV, Faraoni JJ, Ramos RP, Palma-Dibb RG. Influence of different beverages on the microhardness and surface roughness of resin composites. Oper Dent. 2005 Mar-Apr;30(2):213-9. PMid:15853107.

20. Catelan A, Briso AL, Sundfeld RH, Goiato MC, Santos PH. Color stability of sealed composite resin restorative materials after ultraviolet artificial aging and immersion in staining solutions. J Prosthet Dent. 2011 Apr;105(4):236-41. http://dx.doi.org/10.1016/S0022-3913(11)600383. PMid:21458648.

21. Batra R, Kataria P, Kapoor S. Effect of salivary pH on color stability of different flowable composites: a prospective in-vitro study. J Clin Diagn Res. 2016 Oct;10(10):ZC43-6. http://dx.doi.org/10.7860/JCDR/2016/21584.8641. PMid:27891456.

22. Arregui M, Giner L, Ferrari M, Vallés M, Mercadé M. Six-month color change and water sorption of 9 new-generation flowable composites in 6 staining solutions. Braz Oral Res. 2016 Nov;30(1):e123. http://dx.doi.org/10.1590/1807-3107bor-2016.vol30.0123. PMid:27901205.

23. Habib AN, Abdelmoniem SA, Mahmoud SA. Effect of children's drinks on color stability of different dental composites: an in vitro study. J Clin Pediatr Dent. 2017;41(2):120-5. http://dx.doi.org/10.17796/1053-4628-41.2.120. PMid:28288289.

24. Aguiar FHB, Georgetto MH, Soares GP, Catelan A, Santos PH, Ambrosano GM, et al. Effect of different light-curing modes n degree of conversion, staining susceptibility and stain's retention using different beverages in a nanofilled composite resin. J Esthet Restor Dent. 2011 Apr;23(2):106-14. http://dx.doi.org/10.1111/j.1708-8240.2011.00406.x. PMid:21477037. 
25. Bosquiroli V, Franco EB, Pereira JC, Navarro MFL, Mondelli RFL. Fotopolimerização de resina composta com luz halógena e LED: avaliação da resistência à tração de uma resina composta fotopolimerizável em função de diferentes fontes de luz e de tempos de ativação. RGO. 2006 Abr-Jun;54(2):129-33.

\section{CONFLICTS OF INTERESTS}

The authors declare no conflicts of interest.

\section{${ }^{*}$ CORRESPONDING AUTHOR}

Tatiane Cristina Dotta, USP - Universidade de São Paulo, Faculdade de Odontologia, Avenida do Café, Subsetor Oeste, 11 (N-11), 14040-904 Ribeirão Preto - SP, Brasil, e-mail: tatianedotta@usp.br

Received: October 10, 2018

Accepted: October 22, 2018 